\title{
ANALISIS FAKTOR YANG BERHUBUNGAN DENGAN KEPATUHAN PASIEN DI KABUPATEN BANJAR
}

\author{
Analysis Of Factors Related To Patient Compliance In Banjar District
}

\section{Mustaqimah ${ }^{\text {** }}$}

Rina Saputri ${ }^{2}$

\section{Ali Rakhman Hakim ${ }^{3}$}

Reny Indriyani ${ }^{3}$

${ }^{*}$ Universitas Sari Mulia, Banjarmasin, Kalimantan Selatan, Indonesia

${ }^{2}$ Universitas Sari Mulia, Banjarmasin, Kalimantan Selatan, Indonesia

${ }^{3}$ Universitas Sari Mulia, Banjarmasin, Kalimantan Selatan, Indonesia

${ }^{3}$ RSUD Ratu Zaleha

*email: mustaqimah@unism.ac.id

Kata Kunci:

Kepatuhan

Antihipertensi

Pasien Hipertensi

Keywords:

Compliance

Antihypertensive

Hypertension Patients

\begin{abstract}
Abstrak
Hipertensi masih menjadi penyakit yang paling banyak diderita masyarakat di dunia. Provinsi Kalimantan Selatan pada tahun 2018 menjadi provinsi dengan jumlah penderita hipertensi tertinggi di Indonesia. Pasien hipertensi akan melakukan terapi hipertensi seumur hidupnya agar tekanan darah tetap dapat terkontrol dengan baik. Terapi seumur hidup dapat menurunkan kepatuhan pasien dalam mengonsumsi obat hipertensi, hal ini dapat mengakibatkan tujuan terapi menjadi gagal dan dapat menyebabkan munculnya penyakit lain seperti infark miokad dan lainnya. Tujuan dari penelitian ini adalah menganalisis faktor sosidemografi dan faktor klinis yang kemungkinan berhubungan dengan kepatuhan pasien dalam mengkonsumsi obat hipertensi di Kabupaten Banjar. Hasil penelitian menunjukkan mayoritas responden memiliki kepatuhan yang rendah dalam mengkonsumsi obat - obat hipertensi. Analisis menunjukkan faktor sosidemografi berupa jenis kelamin, umur, pekerjaan dan tempat mendapatkan obat serta faktor klinis berupa obat yang digunakan dan kontrol tekanan darah tidak menunjukkan hubungan yang signifikan. Faktor Pendidikan menunjukkan nilai $\mathrm{P}$-value $<0.05$ yang menunjukkan faktor pendidikan memiliki hubungan yang signifikan.
\end{abstract}

\begin{abstract}
Hypertension is still the most common disease in the world. South Kalimantan Province in 2018 became the province with the highest number of hypertension sufferers in Indonesia. Hypertensive patients will undergo hypertension therapy for the rest of their lives so that blood pressure can still be well controlled. Lifelong therapy can reduce patient compliance in taking hypertension drugs, this can result in therapeutic goals being failed and can lead to the emergence of other diseases such as myocardial infarction and others. The purpose of this study was to analyze sociodemographic factors and clinical factors that may be related to patient compliance in taking hypertension drugs in Banjar Regency. The results showed that the majority of respondents had low compliance in consuming hypertension drugs. The analysis showed that sociodemographic factors such as gender, age, occupation and place of getting the drug and clinical factors in the form of drugs used and blood pressure control did not show a significant relationship. The education factor shows a p-value $<0.05$ which indicates the education factor has a significant relationship.
\end{abstract} (C) year The Authors. Published by Institute for Research and Community Services Universitas Muhammadiyah Palangkaraya. This is Open Access article under the CC-BY-SA License (http://creativecommons.org/licenses/by-sa/4.0/). DOI: https://doi.org/10.33084/jsm.vxix.xxx.

\section{PENDAHULUAN}

Hipertensi merupakan penyakit dengan prevalensi yang tinggi, berdasarkan data World Health Organization (WHO), pada tahun 2015 terdapat sekitar I,I3 miliar orang di seluruh dunia mengidap hipertensi, I dari 4 pria dan I dari 5 wanita menderita hipertensi, dan I dari 5 orang dengan hipertensi pada kondisi tidak terkendali atau terkontrol (WHO, 202I). Berdasarkan 
data Laporan Riset Kesehatan Dasar pada tahun 2018 prevalensi hipertensi tertinggi di Indonesia 2018 terdapat pada Provinsi Kalimantan Selatan yang menempati peringkat pertama yaitu sebesar $44,1 \%$ pada umur $>18$ tahun, sedangkan pada data Laporan Riset Kesehatan Dasar yang lalu pada tahun 2013 Provinsi Kalimantan Selatan berada diperingkat kedua yaitu sebesar 25,8 \% pada umur > 18 tahun, berdasarkan data tersebut dapat dilihat terjadi peningkatan angka kejadian hipertensi yang signifikan pada Provinsi Kalimantan Selatan (Kemenkes, 2018).

Hipertensi merupakan penyakit yang tidak dapat disembuhkan, sehingga terapi yang diberikan bertujuan untuk mengontrol tekanan darah dan mencegah komplikasi. Umumnya komplikasi pada penyakit ini dapat mengakibatkan kematian, sehingga penggunaan obat hipertensi harus dikonsumsi seumur hidup. Salah satu faktor penting yang menentukan keberhasilan terapi hipertensi adalah kepatuhan pasien dalam mengkonsumsi obat (Zhou et al., 2018). Ketidakpatuhan yang disengaja ini diartikan sebagai kondisi ketika pasien berperilaku tidak patuh secara disengaja. Alasan yang paling banyak disampaikan oleh pasien sehingga secara sengaja menghentikan pengobatannya adalah takut akan munculnya efek buruk dari penggunaan obat jangka panjang. Alasan lainnya adalah Pasien merasa tidak mengalami gejala dan tanda hipertensi (pasien menganggap jika tekanan darah tinggi pasti mereka merasa pusing) sehingga pasien memiliki persepsi bahwa tekanan darahnya normal.

Berdasarkan berbagai penelitian sebelumnya banyak hal yang kemungkinan besar dapat berhubungan dengan kepatuhan pasien dalam minum obat. Tujuan dari penelitian ini adalah menganalisis karakteristik pasien hipertensi, faktor - faktor yang berhubungan dnegan kepatuhan pasien dalam mengkonsumsi obat hipertensi di Kabupaten Banjar.
Penelitian bersifat observasional analitik dengan menggunakan metode cross sectional. Pengambilan sampel dilakukan di kabupaten Banjar dengan melibatkan 4 Kecamatan yaitu Kecamatan Martapura, Kecamatan Martapura barat, Kecamatan Sungai Tabuk, dan Kecamatan Mataraman. Variabel terikat dalam penelitian ini adalah kepatuhan pasien minum obat hipertensi, sedangkan varibel bebas dalam penelitian ini adalah jenis kelamin, usia, tingkat pendidikan, pekerjaan, Pengumpulan data dilakukan dengan menggunakan kuisionerkepatuhan minum obat MMAS8. Pertanyaan nomor I - 4 dan 6- 7 untuk jawaban "ya" bernilai 0 dan "tidak" bernilai I. Pertanyaan nomor 5 untuk jawaban "ya" bernilai I dan "tidak" bernilai 0 . Pertanyaan nomor 8 untuk jawaban "a" bernilai I, "b" bernilai 0,75, "c" bernilai 0,5, “d" bernilai 0,25 , dan “e” bernilai 0 . Pasien dinyatakan memiliki kepatuhan tinggi jika nilai total kuisioner 8, kepatuhan sedang dengan nilai $6-<8$, dan kepatuhan rendah dengan nilai $<6$.

Analisis data dilakukan dengan analisis univariat dan bivariat. Analisis univariat dilakukan untuk mengetahui profil karakteristik sosiodemograi dan karakteristik klinis dari responden, sedangkan analisis bivariat dilakukan utnuk mengetahui hubungan yang signifikan antara faktor - faktor yang diteliti dengan kepatuhan minum obat pasien hipertensi di Kabupaten Banjar. Analisis bivariat yang digunakan dalam penelitian ini dapat dilihat pada table I.

Tabel I. Analisis bivariat

\begin{tabular}{|c|c|c|c|c|}
\hline $\begin{array}{c}\text { Variabel } \\
\text { bebas }\end{array}$ & $\begin{array}{c}\text { Skala } \\
\text { data }\end{array}$ & $\begin{array}{c}\text { Variabel } \\
\text { terikat }\end{array}$ & $\begin{array}{c}\text { Skala } \\
\text { data }\end{array}$ & $\begin{array}{c}\text { Analisis } \\
\text { Data }\end{array}$ \\
\hline $\begin{array}{c}\text { Jenis } \\
\text { Kelamin }\end{array}$ & \multirow{2}{*}{ Nominal } & \multirow{4}{*}{ Kepatuhan } & \multirow{4}{*}{ Ordinal } & $\begin{array}{c}\text { Chi } \\
\text { Square }\end{array}$ \\
\hline $\begin{array}{l}\text { Obat yang } \\
\text { digunakan }\end{array}$ & & & & \\
\hline $\begin{array}{c}\text { Usia } \\
\text { Pendidikan }\end{array}$ & \multirow[b]{2}{*}{ Ordinal } & & & \multirow{3}{*}{$\begin{array}{c}\text { Spearman } \\
\text { Rank } \\
\text { (Rho) }\end{array}$} \\
\hline $\begin{array}{c}\text { Pekerjaan } \\
\text { Tempat } \\
\text { mendapatkan } \\
\text { obat }\end{array}$ & & & & \\
\hline Kepatuhan & Ordinal & $\begin{array}{l}\text { Kontrol } \\
\text { tekana } \\
\text { Darah }\end{array}$ & Ordinal & \\
\hline
\end{tabular}

\section{METODOLOGI}


Penelitian ini telah mendapatkan persetujuan etik (ethical clearance) dari Komisi Etik Universitas Sari Mulia dengan nomor 036/ KE-LPPM/UNISM/VII/202I.

\section{HASIL DAN PEMBAHASAN}

Tabel 2. Karakteristik Sosidemografi Responden

\begin{tabular}{|c|c|c|c|c|}
\hline \multirow{2}{*}{$\frac{\text { No }}{1}$} & \multicolumn{2}{|c|}{ Kategori } & \multirow{2}{*}{$\begin{array}{c}\mathrm{n} \\
53\end{array}$} & \multirow{2}{*}{$\begin{array}{r}\% \\
75.71\end{array}$} \\
\hline & Jenis & Perempuan & & \\
\hline & kelamin & Laki - laki & 17 & 24.29 \\
\hline & & Total & 70 & 100 \\
\hline \multirow[t]{3}{*}{2} & \multirow[t]{3}{*}{ Usia } & $<50$ tahun & 25 & 35.71 \\
\hline & & $>50$ tahun & 45 & 64.29 \\
\hline & & Total & 70 & 100 \\
\hline \multirow[t]{4}{*}{3} & \multirow[t]{4}{*}{ Pendidikan } & SD & 53 & 75.71 \\
\hline & & SMP & 7 & 10.00 \\
\hline & & SMA & 10 & 14.29 \\
\hline & & Total & 70 & 100 \\
\hline \multirow[t]{6}{*}{4} & \multirow[t]{6}{*}{ Pekerjaan } & IRT & 31 & 44.29 \\
\hline & & Petani & 31 & 44.29 \\
\hline & & Swasta & 3 & 4.29 \\
\hline & & Petugas Desa & I & 1.43 \\
\hline & & Tidak Bekerja & 4 & 5.71 \\
\hline & & Total & 70 & 100 \\
\hline \multirow[t]{8}{*}{5} & \multirow{8}{*}{$\begin{array}{l}\text { Tempat } \\
\text { mendapatk } \\
\text { an obat }\end{array}$} & Apotek & II & 15.7 \\
\hline & & $\begin{array}{l}\text { Pasarl } \\
\text { Warung }\end{array}$ & 13 & 18.6 \\
\hline & & Puskesmas & 23 & 32.9 \\
\hline & & Posyandu & II & 15.7 \\
\hline & & $\begin{array}{l}\text { Praktik } \\
\text { Dokter }\end{array}$ & 5 & 7.1 \\
\hline & & Baksos & 3 & 4.3 \\
\hline & & $\begin{array}{l}\text { Nakes lain } \\
\text { diluar } \\
\text { kompetensi }\end{array}$ & 4 & 5.7 \\
\hline & & Total & 70 & 100 \\
\hline
\end{tabular}

Tabel 3. Karakteristik Hubungan umur dan Jenis Kelamin

\begin{tabular}{ccccccc}
\hline Umur & \multicolumn{2}{c}{$\mathrm{L}$} & \multicolumn{2}{c}{$\mathrm{P}$} & \multicolumn{2}{c}{ total } \\
\cline { 2 - 7 } & $\mathrm{n}$ & $\%$ & $\mathrm{n}$ & $\%$ & $\mathrm{n}$ & $\%$ \\
\hline $\begin{array}{c}<50 \\
\text { tahun }\end{array}$ & 6 & 8.57 & 19 & 27.14 & 25 & $35.7 \mathrm{I}$ \\
\hline $\begin{array}{c}>50 \\
\text { tahun }\end{array}$ & $\mathrm{II}$ & $15.7 \mathrm{I}$ & 34 & 48.57 & 45 & 64.29 \\
\hline
\end{tabular}

Jumlah total responden yang terlibat dalam penelitian ini adalah 70 responden. Mayoritas responden yang terlibat dalam penelitian ini adalah perempuan dengan persentasi $75,71 \%$, karena mayoritas responden yang datang untuk berobat adalah perempuan. Hasil penelitian ini juga menunjukkan perempuan lebih sering mengalami hipertensi dibandingkan laki - laki. Penelitian ini sejalan dengan penelitian (Kusumawaty et al., 2016) yang menunjukkan mayoritas responden terbesar yang mengalami hipertensi adalah perempuan.
Tingginya angka kejadian hipertensi pada Wanita dapat dipengaruhi oleh beberapa faktor antara lain penggunaan kontrasepsi hormonal, tingginya angka kejadian hipertensi pada kehamilan yang tidak terkontrol sehingga berlanjut menjadi hipertensi kronis (Grundy et al., 2019; Lukito et al., 2019). Mayoritas responden berusia lebih dari 50 tahun dengan persentasi $64.29 \%$. Semakin bertambahnya usia maka semakin tinggi resiko untuk mengalami hipertensi, karena efisiensi sistem kardiovaskular mengalami penurunan dan masalah - masalah yang berhubungan dengan fungsi sistem tersebut. Pada Wanita dengan usia $>50$ tahun atau masa menopause angka kejadian hipertensi lebih tinggi dibandingkan dengan laki - laki, karena pengaruh perubahan hormone estrogen, sedangkan pada usia muda angka kejadian hipertensi lebih tinggi pada laki - laki. Berdasarkan tabel 2 mayoritas responden berusia $>50$ tahun yang mengalami hipertensi adalah Wanita. Hasil penelitian ini sejalan dengan penelitian (Andria et al., 202I) menunjukkan mayoritas responden yang mengalami hipertensi adalah Wanita dengan usia di atas 45 tahun. Mayoritas Pendidikan responden yang terlibat dalam penelitian ini adalah SD sebesar 75,7I \%. Berdasarkan hasil wawancara sederhana kepada responden, mayoritas responden berpendidikan rendah karena tuntutan membantu orang tua dan bekerja. Mayoritas responden bekerja sebagai petani dan juga ibu rumah tangga. Tabel I juga menunjukkan tempat mendapatkan obat hipertensi responden di kabupaten Banjar sangat variatif, mayoritas mendapatkan di Puskesmas sebesar $32,9 \%$.

Tabel 4. Karakteristik Klinis Responden

\begin{tabular}{ccccc}
\hline No & \multicolumn{2}{c}{ Kategori } & $\begin{array}{c}\text { Jumlah } \\
\text { Responden }\end{array}$ & $\%$ \\
\hline I & $\begin{array}{l}\text { Tekanan } \\
\text { Darah }\end{array}$ & terkontrol & 5 & 7.1 \\
\cline { 2 - 5 } & & $\begin{array}{c}\text { Tidak } \\
\text { terkontrol }\end{array}$ & 65 & 92.9 \\
\hline 2 & Total & 70 & 100 \\
\cline { 2 - 5 } & $\begin{array}{c}\text { Obat Yang } \\
\text { Digunakan }\end{array}$ & Amlodipin & 33 & 47.1 \\
\cline { 3 - 5 } & $\begin{array}{c}\text { Captopril } \\
\text { obat apa yang } \\
\text { digunakan }\end{array}$ & 12 & 17.1 \\
\hline
\end{tabular}


Total
Data tekanan darah menujukkan mayoritas
responden memiliki tekanan darah yang tidak
terkontrol. Hipertensi merupakan salah satu penyakit
degeneratif yang tidak bisa disembuhkan, tetapi bisa di
kontrol. Target keberhasilan terapi pada pasien
hipertensi adalah tekanan darah yang terkontrol. Obat yang digunakan responden dalam mengatasi hipertensi Amlodipin dan Captorpril, selebihnya responden tidak mengingat obat hipertensi yang digunakan. Amlodipin merupakan Obat hipertensi golongan Penghambat kanal kalsium (Calcium channel blockerl CCB) yang menyebabakn relaksasi otot polos arteri yang selanjutnya dapat menurunkan resistensi perifer total sehingga tekanan darah dapat menurun. Efek antihipertensi dari CCB berhubungan dengan dosis, bila dosis ditambah maka efek antihipertensi semaki besar dan tidak menimbulkan efek toleransi. CCB tidak dipengaruhi oleh asupan garam sehingga dapat digunakan pada pasien yang tidak mematuhi diet garam. Captropril merupakan obat hipertensi golongan Penghambat enzim angiotensin (Angiotensin converting enzim inhibitorl ACEi) yang akan menghambat perubahan angiotensin I menjadi angiotensin II sehingga dapat menurunkan tekanan darah. Obat antihipertensi golongan $\mathrm{CCB}$ dan ACEi merupakan pilihan terapi utama pada pasien hipertensi (Grundy et al., 2019; Lukito et al., 2019). Ditinjau dari mortalitas tidak ada perbedaan bermakna antara CCB maupun ACEi dalam pengobatan hipertensi. Mayoritas responden menggunakan Amlodipin dengan persentasi 47,1\%. Captopril dan Amlodipin merupakan obat hipertensi denga efektifitas yang baik, penggunaan amlodipine lebih banyak digunakan karena resiko efek samping batuk kering lebih kecil dibandingkan captopril, sehingga lebih disukai untuk dikonsumsi. Hasil ini sesuai dengan penelitian (Andriyana, 2018) yang menunjukkan obat antihipertensi tunggal yang paling banyak diresepkan pada pasien geriatric di instalasi rawat inap RSUD Dr. Moewardi Surakarta adalah amlodipine sebesar 32,78\%. Hasil penelitian ini juga sesuai dengan penelitian (Ardhany et al., 2018) yang menunjukkan mayoritas obat antihipertensi yang digunakan di RSUD Mas Amsyar Kasongan Kabupaten Katingan adalah Amlodipin sebesar 38\%.

Tabel 5. Profil Kepatuhan Responden

\begin{tabular}{lcc}
\hline Kepatuhan & $\begin{array}{c}\text { Jumlah } \\
\text { responden }\end{array}$ & $\%$ \\
\hline Rendah & 53 & 75.71 \\
\hline Sedang & 12 & 17.14 \\
\hline Tinggi & 5 & 7.14 \\
\hline Total & 70 & 100 \\
\hline
\end{tabular}

Profil kepatuhan minum obat hipertensi menunjukkan mayoritas responden memiliki kepatuhan rendah, dengan persentasi 77,1\%. Hasil penelitian ini juga sejalan dengan penelitian (Sepalawandika \& Gunawan, 2016) yang menunjukkan kepatuhan minum obat hipertensi pada pasien hipertensi di Lingkungan Universitas Tarumanegara mayoritas memiliki kepatuhan yang rendah yaitu 95,8\%. Hasil ini juga sesuai dengan penelitian (Sinuraya et al., 2018) yang menunjukkan lebih dari $50 \%$ pasien hipertensi di fasilitas Kesehatan tingkat pertama di Kota Bandung masih memiliki tingkat kepatuhan yang rendah terhadap pengobatannya. Hipertensi merupakan penyakit yang memerlukan terapi seumur hidup, sehingga kepatuhan minum obat merupakan salah satu faktor yang penting untuk dapat mencapai target terapi hipertensi. Tujuan pemberian obat antihipertensi secara rutin adalah agar obat selalu berada dalam sirkulasi darah agar tekanan darah dalam keadaan terkontrol (Sepalawandika \& Gunawan, 2016).

Tabel 6. Hubungan Jenis Kelamin dengan Kepatuhan Responden

\begin{tabular}{|c|c|c|c|c|c|c|c|c|c|}
\hline Jeni & \multicolumn{6}{|c|}{ Kepatuhan } & \multirow{3}{*}{$\begin{array}{l}\text { To } \\
\text { tal }\end{array}$} & \multirow{3}{*}{$\begin{array}{c}P \text { - } \\
\text { valu } \\
\text { e }\end{array}$} & \multirow{3}{*}{$\begin{array}{l}C \\
C\end{array}$} \\
\hline$s$ & \multicolumn{2}{|c|}{ Rendah } & \multicolumn{2}{|c|}{ Sedang } & \multicolumn{2}{|c|}{ Tinggi } & & & \\
\hline $\begin{array}{c}\text { Kela } \\
\text { min }\end{array}$ & $\mathrm{n}$ & $\%$ & $\mathrm{n}$ & $\%$ & $n$ & $\%$ & & & \\
\hline $\begin{array}{l}\text { Per } \\
\text { emp } \\
\text { uan }\end{array}$ & 42 & 79.25 & 8 & 34.78 & 3 & 5.66 & 53 & & \\
\hline $\begin{array}{c}\text { Laki } \\
\text { - } \\
\text { Laki }\end{array}$ & II & 64.7I & 4 & 12.47 & 2 & 11.76 & 17 & 457 & 0.148 \\
\hline
\end{tabular}


Nilai $\mathrm{p}$ - value > 0.05 yang menunjukkan tidak ada hubungan yang signifikan antara jenis kelamin dan

\begin{tabular}{|c|c|c|c|c|c|c|c|c|c|}
\hline \multirow{3}{*}{$\begin{array}{l}\text { Pen } \\
\text { didi } \\
\text { kan }\end{array}$} & \multicolumn{6}{|c|}{ Kepatuhan } & \multirow{3}{*}{$\begin{array}{l}\mathrm{T} \\
\text { ot } \\
\text { al }\end{array}$} & \multirow{3}{*}{$\begin{array}{c}P- \\
\text { value }\end{array}$} & \multirow{3}{*}{$\mathrm{CC}$} \\
\hline & \multicolumn{2}{|c|}{ Rendah } & \multicolumn{2}{|c|}{ Sedang } & \multicolumn{2}{|c|}{ Tinggi } & & & \\
\hline & $\mathrm{n}$ & $\%$ & $\mathrm{n}$ & $\%$ & $\mathrm{n}$ & $\%$ & & & \\
\hline SD & 43 & $\begin{array}{c}8 I . I \\
3\end{array}$ & 9 & $\begin{array}{c}16.9 \\
8\end{array}$ & I & 1.89 & 53 & & \\
\hline $\begin{array}{c}\text { SM } \\
P\end{array}$ & 5 & $\begin{array}{c}71.4 \\
3\end{array}$ & I & $\begin{array}{c}14.2 \\
9\end{array}$ & I & $\begin{array}{c}14.2 \\
9\end{array}$ & 7 & $\begin{array}{l}0.00 \\
3\end{array}$ & $\begin{array}{l}0.31 \\
3\end{array}$ \\
\hline $\begin{array}{c}\text { SM } \\
\text { A }\end{array}$ & 5 & $\begin{array}{c}50.0 \\
0\end{array}$ & 2 & $\begin{array}{c}20.0 \\
0\end{array}$ & 3 & $\begin{array}{c}30.0 \\
0\end{array}$ & 10 & & \\
\hline
\end{tabular}

kepatuhan. Nilai Contingency coefficient menunjukkan nilai yang mendekati 0 yang menunjukkan tingkat hubungan bersifat lemah. Hasil penelitian ini sejalan dengan penelitian (Puspita, 2016) yang menunjukkan tidak ada hubungan antara jenis kelamin dengan kepatuhan dalam menjalani pengobatan hipertensi di Puskesmas Gunungpati Kota Semarang. Berdasarkan data pada tabel 6 dapat dilihat laki - laki memiliki kepatuhan yang tinggi, akan tetapi perbedaan persentasi pada kedua kelompok tidak jauh berbeda. Hasil penelitian ini juga sejalan dengan penelitian (Hidayanti et al., 20l3) yang menunjukkan tidak ada hubungan antara jenis kelamin dengan kepatuhan penggunaan obat pada pasien hipertensi. Hasil ini juga sesuai dengan telaah sistematik oleh (Edi, 2020) yang menunjukkan pada kasus penyakit kronis laki - laki memiliki kepatuhan yang lebih tinggi dibandingkan perempuan terutama pada usia $>60$ tahun.

Tabel 7. Hubungan Usia dengan Kepatuhan Responden

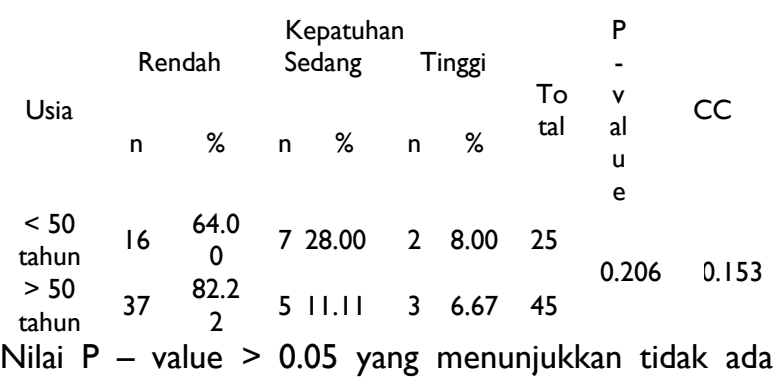
hubungan yang signifikan antara umur dan kepatuhan. Nilai Corellation coefficient menunjukkan nilai yang mendekati 0 yang menunjukkan tingkat hubungan bersifat lemah. Hasil penelitian ini sejalan dengan penelitian (Pramana et al., 2019) yang menunjukkan faktor umur tidak memiliki hubungan yang signifikan dengan kepatuhan. Hasil penelitian ini sesuai dengan teori pada penelitian lain yang menunjukkan umur tidak berpengaruh terhadap Tindakan sesorang karena adanya faktor - faktor lain yang dapat mempengaruhi kepatuhan dalam pengobatan.

Tabel 8. Hubungan Tingkat Pendidikan dengan Kepatuhan Responden

Nilai $P$ - value $<0.05$ yang menunjukkan ada hubungan yang signifikan antara pendidikan dan kepatuhan. Nilai Corellation coefficient menunjukkan nilai hubungan bersifat cukup kuat. Berdasarkan data pada table 8 dapat dilihat semakin tinggi Pendidikan maka semakin tinggi juga tingkat kepatuhan responden dalam mengkonsumsi obat hipertensi. Hasil penelitian ini sejalan dengan penelitian (Puspita, 2016) yang menunjukkan adanya hubungan yang signifikan antara tingkat Pendidikan dengan kepatuhan dalam menjalani pengobatan hipertensi. Hasil ini juga sesuai dengan penelitian yang dilakukan (Boima et al., 2015) menunjukkan terdapat hubungan antara tingkat Pendidikan dengan kepatuhan pengobatan hipertensi. Berdasarkan teori (Notoatmodjo, 2012) menunjukkan salah satu faktor yang dapat mempengaeruhi pengetahuan seseorang adalah Pendidikan. Semakin tinggi tingkat Pendidikan maka semakin luas juga tingkat pengetahuannya.

Tabel 9. Hubungan Pekerjaan dengan Kepatuhan Responden

\begin{tabular}{|c|c|c|c|c|c|c|c|c|c|}
\hline \multirow{3}{*}{$\begin{array}{l}\text { Peke } \\
\text { rjaan }\end{array}$} & \multicolumn{6}{|c|}{ Kepatuhan } & \multirow{3}{*}{$\begin{array}{l}- \text { Tot } \\
- \text { al }\end{array}$} & \multirow{3}{*}{$\begin{array}{c}P \text { - } \\
\text { valu } \\
\text { e }\end{array}$} & \multirow{3}{*}{$\mathrm{CC}$} \\
\hline & \multicolumn{2}{|c|}{ Rendah } & \multicolumn{2}{|c|}{ Sedang } & \multicolumn{2}{|c|}{ Tinggi } & & & \\
\hline & $n$ & $\%$ & $\mathrm{n}$ & $\%$ & $\mathrm{n}$ & $\%$ & & & \\
\hline IRT & 24 & 75.00 & 5 & 15.63 & 3 & $\begin{array}{c}9.3 \\
8\end{array}$ & 32 & & \\
\hline Petani & 23 & 74.19 & 6 & 19.35 & 2 & $\begin{array}{c}6.4 \\
5\end{array}$ & 31 & & \\
\hline Swasta & 3 & $\begin{array}{c}100.0 \\
0\end{array}$ & 0 & 0.00 & 0 & $\begin{array}{c}0.0 \\
0\end{array}$ & 3 & 0.964 & 0.006 \\
\hline $\begin{array}{l}\text { Petuga } \\
\text { s Desa }\end{array}$ & 0 & 0.00 & I & $\begin{array}{c}100.0 \\
0\end{array}$ & 0 & $\begin{array}{c}0.0 \\
0\end{array}$ & I & & \\
\hline $\begin{array}{c}\text { Tidak } \\
\text { Bekerj } \\
\text { a }\end{array}$ & 3 & $\begin{array}{c}100.0 \\
0\end{array}$ & 0 & 0.00 & 0 & $\begin{array}{c}0.0 \\
0\end{array}$ & 3 & & \\
\hline
\end{tabular}


Nilai $P$ - value > 0.05 yang menunjukkan tidak ada hubungan yang signifikan antara umur dan kepatuhan. Nilai Corellation coefficient menunjukkan nilai yang mendekati 0 yang menunjukkan tingkat hubungan bersifat lemah. Hasil penelitian ini sejalan dengan penelitian (Puspita, 2016) yang menunjukkan tidak ada hubungan yang signifikan antara status pekerjaan dengan kepatuhan dalam menjalani pengobatan hipertensi di Puskesmas Gunungpati Kota Semarang. Hasil ini juga sejalan dengan penelitian (Jaya, 2009) yang juga menunjukkan tidak ada perbedaan yang signifikan antara status pekerjaan dengan kepatuhan pengobatan pasien hipertensi. Pada tabel 9 menunjukkan $100 \%$ pasien yang tidak bekerja dan yang bekerja swasta dalam hal ini berdagang memiliki kepatuhan yang rendah. Pada tabel 9 juga menunjukkan mayoritas responden yang bekerja sebagai petani dan IRT memiliki kepatuhan yang rendah. Hasil penelitian ini sejalan dengan telaah sistematik yang dilakukan (Edi, 2020) yang menunjukkan rendahnya pendapatan dan adanya kendala keuangan sebagai penyebab ketidakpatuhan pada pengobatan. Hasil telaah juga menunjukkan terdapat perbedaan kepatuhan pada negara yang berpendapatan rendah dengan negara yang berpendapatan menengah meskipun tidak diketahui hubungannya.

Tabel 10. Hubungan tempat mendapatkan obat dengan kepatuhan responden

\begin{tabular}{|c|c|c|c|c|c|c|c|}
\hline \multirow{3}{*}{$\begin{array}{c}\text { Tempat } \\
\text { mendapa } \\
\text { tkan obat }\end{array}$} & \multicolumn{4}{|c|}{ Kepatuha } & \multirow{3}{*}{$\begin{array}{l}\text { To } \\
\text { tal }\end{array}$} & \multirow{3}{*}{$\begin{array}{c}\mathrm{P} \text { - } \\
\text { value }\end{array}$} & \multirow{3}{*}{$\mathrm{CC}$} \\
\hline & \multicolumn{2}{|c|}{ Rendah } & Sedang & Tinggi & & & \\
\hline & $\mathrm{n}$ & $\%$ & $\mathrm{n} \quad \%$ & $\mathrm{n} \quad \%$ & & & \\
\hline Apotek & 6 & 54.55 & 327.27 & 218.18 & 11 & & \\
\hline $\begin{array}{c}\text { Pasar/ } \\
\text { Warung }\end{array}$ & $\begin{array}{l}1 \\
1\end{array}$ & 84.62 & I 7.69 & I 7.69 & 13 & & \\
\hline $\begin{array}{l}\text { Puskesm } \\
\text { as }\end{array}$ & $\begin{array}{l}1 \\
7\end{array}$ & 73.91 & 521.74 & I 4.35 & 23 & & \\
\hline Posyandu & 8 & 72.73 & 327.27 & $0 \quad 0.00$ & II & & \\
\hline $\begin{array}{l}\text { Praktik } \\
\text { Dokter }\end{array}$ & 4 & 80.00 & $0 \quad 0.00$ & I 20.00 & 5 & $\begin{array}{c}0.72 \\
9\end{array}$ & 0.042 \\
\hline Baksos & 3 & $\begin{array}{c}100.0 \\
0\end{array}$ & $0 \quad 0.00$ & $0 \quad 0.00$ & 3 & & \\
\hline $\begin{array}{c}\text { Nakes } \\
\text { lain } \\
\text { diluar } \\
\text { kompete } \\
\text { nsi }\end{array}$ & 4 & $\begin{array}{c}100.0 \\
0\end{array}$ & $0 \quad 0.00$ & $0 \quad 0.00$ & 4 & & \\
\hline
\end{tabular}

Nilai $P$ - value > 0.05 yang menunjukkan tidak ada hubungan yang signifikan antara dan kepatuhan. Nilai Corellation coefficient menunjukkan nilai tempat mendapatkan obat yang mendekati 0 yang menunjukkan tingkat hubungan bersifat lemah. Obat harus didapatkan dari tempat yang memiliki legalitas sehingga dapat dijamin manfaat, keamanan dan kualitasnya. Selain itu jika mendapatkan obat di tempat yang legal maka informasi yang didapatkan juga dapat dipercaya karena diberikan langsung oleh tenaga Kesehatan yang sudah terlatih (Kemenkes, 20I8). Hasil penelitian menunjukkan responden dengan kepatuhan tinggi mayoritas adalah responden yang mendapatkan obat di Apotek dan Praktik Dokter. Hal ini sesuai dengan teori dimana di Apotek terdapat tenaga kefarmasian khususnya Apoteker yang dapat memberikan informasi dengan tepat kepada pasien hipertensi yang memerlukan terapi seumur hidup. Pemberian obat pada praktik kedokteran juga menunjukkan kepatuhan yang tinggi, akan tetapi pemberian obat langsung atau dispensing obat oleh dokter hanya diperkenankan di daerah tertentu yang tidak ada fasilitas Kesehatan seperti apotek.

Tabel II. Hubungan Obat yang digunakan dengan Kepatuhan Responden

\begin{tabular}{|c|c|c|c|c|c|c|c|c|c|}
\hline \multirow{3}{*}{$\begin{array}{l}\text { Obat Yang } \\
\text { Digunakan }\end{array}$} & \multicolumn{6}{|c|}{ Kepatuhan } & \multirow{3}{*}{$\begin{array}{l}\mathrm{T} \\
\text { ot } \\
\text { al }\end{array}$} & \multirow{3}{*}{$\begin{array}{c}P \text { - } \\
\text { valu } \\
\text { e }\end{array}$} & \multirow{3}{*}{ CC } \\
\hline & \multicolumn{2}{|c|}{ Rendah } & \multicolumn{2}{|c|}{ Sedang } & \multicolumn{2}{|c|}{ Tinggi } & & & \\
\hline & $\mathrm{n}$ & $\%$ & $\mathrm{n}$ & $\%$ & $\mathrm{n}$ & $\%$ & & & \\
\hline Amlodipin & 23 & 69.70 & 7 & 21.21 & 3 & 9.09 & 33 & & \\
\hline Captopril & II & 91.67 & I & 8.33 & 0 & 0.00 & 12 & & \\
\hline $\begin{array}{c}\text { Tidak ingat } \\
\text { obat apa } \\
\text { yang } \\
\text { digunakan }\end{array}$ & 19 & 76.00 & 4 & 16.00 & 2 & 8.00 & 25 & 0.507 & 0.081 \\
\hline
\end{tabular}

Nilai $P$ - value > 0.05 yang menunjukkan tidak ada hubungan yang signifikan antara obat yang digunakan dan kepatuhan. Nilai Corellation coefficient menunjukkan nilai yang mendekati 0 yang menunjukkan tingkat hubungan bersifat lemah. Hasil penelitian ini sejalan dengan penelitian (Pramana et al., 2019) yang 
menunjukkan jenis obat yang digunakan tidak memiliki hubungan yang signifikan dengan kepatuhan.

Tabel 12. Hubungan Tingkat Kepatuhan dengan Kontrol Tekanan Darah Responden

\begin{tabular}{|c|c|c|c|c|c|c|c|}
\hline \multirow{3}{*}{$\begin{array}{l}\text { Tingkat } \\
\text { Kepatu } \\
\text { han }\end{array}$} & \multicolumn{4}{|c|}{ Kontrol Tekanan Darah } & \multirow{3}{*}{$\begin{array}{l}\text { To } \\
\text { tal }\end{array}$} & \multirow{3}{*}{$\begin{array}{c}P \text { - } \\
\text { value }\end{array}$} & \multirow{3}{*}{$\mathrm{CC}$} \\
\hline & \multicolumn{2}{|c|}{ Terkontrol } & \multicolumn{2}{|c|}{$\begin{array}{c}\text { Tidak } \\
\text { Terkontrol }\end{array}$} & & & \\
\hline & $\mathrm{n}$ & $\%$ & $\mathrm{n}$ & $\%$ & & & \\
\hline Rendah & 2 & 3.77 & 51 & 96.23 & 53 & & \\
\hline Sedang & 2 & 16.67 & 10 & 83.33 & 12 & 0.333 & 0.175 \\
\hline Tinggi & 0 & 0.00 & 5 & 100.00 & 5 & & \\
\hline
\end{tabular}

ada hubungan yang signifikan antara tingkat kepatuhan dan kontrol tekanan darah. Nilai Corellation coefficient menunjukkan nilai yang mendekati 0 yang menunjukkan tingkat hubungan bersifat lemah. Hasil penelitian ini sejalan dengan penelitian (Mutmainah \& Rahmawati, 2010) yang menenujukkan korelasi antara kepatuhan dengan penurunan tekanan darah sangat rendah, tingkat kepatuhan mempengaruhi keberhasilan terapi sebesar 18,03\% (Mutmainah \& Rahmawati, 20I0). Hasil ini tidak sejalan dengan penelitian Cahyani (2018) yang menunjukkan kepatuhan memiliki hubungan yang signifikan dengan keberhasilan target terapi (Cahyani, 2018). Tabel 12 menunjukkan 5 pasien dengan tingkat kepatuhan tinggi tetapi tekanan darah tidak terkontrol dengan baik. Kepatuhan merupakan salah satu faktor yang mempengaruhi keberhasilan terapi hipertensi. Pasien sudah memiliki kepatuhan yang tinggi tetapi target kontrol tekanan darah masih belum tercapai, hal ini menunjukkan pasien tersebut perlu di arahkan untuk berkonsultasi dengan dokter, karena kemungkinan obat yang didapatkan pasien kurang adekuat ataupun pasien memiliki faktor pemicu lainnya yang dapat menyebabkan tekanan darah tidak terkontrol.

Banyak faktor yang berhubungan dengan kepatuhan pasien pada pengobatan sehingga sulit untuk memprediksi penyebab ketidakpatuhan pada tingkat individu. Berdasarkan hal tersebut perlu pengembangan intervensi untuk meningkatkan kepatuhan pasien dalam mengkonsumsi obat hipertensi.

\section{KESIMPULAN}

Profil kepatuhan minum obat pada pasien hipertensi di kabupaten Banjar dengan melibatkan 4 Kecamatan yaitu Kecamatan Martapura, Kecamatan Martapura barat, Kecamatan Sungai Tabuk, dan Kecamatan Mataraman masih menunjukkan mayoritas pasien memiliki kepatuhan yang rendah. Hal tersebut dapat dipengaruhi oleh berbagai faktor, diantara lain karakteristik sosidemeografi dan klini pasien di daerah tersebut. Faktor Pendidikan menunjukkan nilai $\mathrm{p}$-value < 0.05 yang menunjukkan faktor pendidikan memiliki hubungan yang signifikan. Berdasarkan hasil tersebut, kedepannya dapat diberikan Edukasi untuk meningkatkan kepatuhan minum obat baik kepada pasien, tenaga Kesehatan (tim yang terlibat) dalam memberikan obat hipertensi kepada pasien.

\section{UCAPAN TERIMA KASIH}

Ucapan terima kasih diberikan kepada Universitas Sari Mulia yang telah memfasilitasi kegiatan penelitian ini.

\section{REFERENSI}

I. WHO. (202I). Hypertension. WHO. https://www.who.int/news-room/factsheets/detail/hypertension

2. Kemenkes. (2018). Laporan Nasional RKD20I8. In Badan Penelitian dan Pengembangan Kesehatan (p. 198).

http://labdata.litbang.kemkes.go.id/images/downloa d/laporan/RKD/2018/Laporan_Nasional_RKD20I 8 FINAL.pdf

3. Zhou, D., Xi, B., Zhao, M., Wang, L., \& Veeranki, S. P. (20I8). Uncontrolled hypertension increases risk of all-cause and cardiovascular disease mortality in US adults: The NHANES III Linked Mortality Study. Scientific Reports, 8(I), I-7. https://doi.org/10.1038/s4I598-018-27377-2

4. Kusumawaty, J., Hidayat, N., \& Ginanjar, E. (2016). Hubungan Jenis Kelamin dengan Intensitas 
Hipertensi pada Lansia di Wilayah Factors Related Events Sex with Hypertension in Elderly Work Area Health District Lakbok Ciamis. Jurnal Mutiara Medika, I6(2), 46-5I.

5. Grundy, S. M., Stone, N. J., Bailey, A. L., Beam, C., Birtcher, K. K., Blumenthal, R. S., Braun, L. T., de Ferranti, S., Faiella-Tommasino, J., Forman, D. E., Goldberg, R., Heidenreich, P. A., Hlatky, M. A., Jones, D. W., Lloyd-Jones, D., Lopez-Pajares, N., Ndumele, C. E., Orringer, C. E., Peralta, C. A., ... $\begin{array}{lll}\text { Yeboah, } & \text { (2019). } & \end{array}$ AHA/ACC/AACVPR/AAPA/ABC/ACPM/ADA/AG S/APhA/ASPC/NLA/PCNA Guideline on the Management of Blood Cholesterol: A Report of the American College of Cardiology/American Heart Association Task Force on Clinical Practice Guidelines. Journal of the American College of Cardiology, 73(24), e285-e350. https://doi.org/10.1016/j.jacc.2018.11.003

6. Lukito, A. A., Harmeiwaty, E., \& Hustrini, N. M. (2019). Konsensus Penatalaksanaan Hipertensi 2019. 118.

http://www.inash.or.id/upload/event/event_Update _konsensus_2019123191.pdf

7. Andriyana, N. D. (20/8). Evaluasi Terapi Penggunaan Obat Antihipertensi Pada Pasien Geriatri Di Instalasi Rawat Inap Rsud Dr. Moewardi Surakarta Tahun 2016. SKRIPSI.

8. Ardhany, S. D., Pandaran, W., Rizki, M., Pratama, F., Palangkaraya, U. M., \& Hospital, M. A. (20I8). Profil Penggunaan Obat Antihipertensi Di RSUD Mas Amsyar Kasongan Kabupaten Katingan. Borneo Journal of Pharmacy, I(I), 47-50.

9. Sepalawandika, A., \& Gunawan, S. (2016). Profil Kepatuhan Minum Obat Antihipertensi Pada Pasien Hipertensi Di Lingkungan Universitas Tarumanegara Periode Juli-Desember 2015. Seminar Nasional Hasil Penerapan Penelitian Dan Pengabdian Pada Masyarakt III 20I6, 638-654.

10. Sinuraya, R. K., Destiani, D. P., Puspitasari, I. M., \& Diantini, A. (2018). Medication Adherence among Hypertensive Patients in Primary Healthcare in Bandung City. Indonesian Journal of Clinical Pharmacy, 7(2), 124-133. https://doi.org/10.154I6/ijcp.2018.7.2.124
II. Puspita, E. (2016). MENJALANI PENGOBATAN ( Studi Kasus di Puskesmas Gunungpati Kota Semarang ). Skripsi.

12. Hidayanti, P., Ningsih, E. S., Padmasari, S., \& Saepudin. (20/3). Kepatuhan Penggunaan Obat pada Pasien Hipertensi di Puskesmas. Jurnal Farmasi Indonesia, 6(April), 246-253.

13. Edi, I. G. M. S. (2020). Faktor-Faktor Yang Mempengaruhi Kepatuhan Pasien Pada Pengobatan. Jurnal Ilmiah Medicamento, I(I), I-8. https://doi.org/10.36733/medicamento.vlil.719

14. Pramana, G. A., Dianingati, R. S., \& Saputri, N. E. (2019). Faktor-Faktor yang Mempengaruhi Kepatuhan Minum Obat Pasien Hipertensi Peserta Prolanis di Puskesmas Pringapus Kabupaten Semarang. Indonesian Journal of Pharmacy and Natural Produc, 02(I), 10-17.

15. Boima, V., Ademola, A. D., Odusola, A. O., Agyekum, F., Nwafor, C. E., Cole, H., Salako, B. L., Ogedegbe, G., \& Tayo, B. O. (20I5). Factors Associated with Medication Nonadherence among Hypertensives in Ghana and Nigeria. International Journal of Hypertension, 2015. https://doi.org/10.1155/2015/2057/6

16. Notoatmodjo, S. (20/2). Promosi kesehatan dan Perilaku Kesehatan. In Rineka cipta. Rineka cipta

17. Jaya, N. T. A. A. (2009). Faktor-faktor yang berhubungan dengan tingkat kepatuhan pasien dalam minum obat antihipertensi di puskesma Pamulang Kota Tangerang Selatan Banten Tahun 2009. Skripsi.

18. Mutmainah, N., \& Rahmawati, M. (2010). Hubungan Antara Kepatuhan Penggunaan Obat Dan Keberhasilan Terapi Pada Pasien Hipertensi Di Rumah Sakit Daerah Surakarta Tahun 2010. Pharmacon, I I (2), 5I-56.

19. Cahyani, F. M. (20/8). Hubungan Kepatuhan Minum Obat Antihipertensi Terhadap Tercapainya Target Terapi Pasien Hipertensi di Puskesmas Wirobrajan Yogyakarta. Journal of Pharmaceutical Science and Medical Research, I(2), 10. https://doi.org/10.25273/pharmed.vli2.298I

20. Andria, K. M., Widati, S., \& Nurmala, I. (202I). 
The Characteristics of Hypertension Patients at Puskesmas Waru, Pamekasan in 2018. Jurnal PROMKES, $9(1)$, 11. https://doi.org/10.20473/jpk.v9.il.2021.II-17 